\title{
A Morte dos Avós na Literatura Infantil: análise de três álbuns ilustrados
}

Teresa de Lurdes Frutuoso Mendes'

'Instituto Politécnico de Portalegre - Portugal

RESUMO - A Morte dos Avós na Literatura Infantil: análise de três álbuns ilustrados $^{1}$. No respeito pela inteligência e pela sensibilidade da criança, cada vez mais a literatura infantil contemporânea declina temas tradicionalmente considerados tabu, como é o caso da morte, através da criação de universos efabulatórios e pictóricos de grande qualidade estético-literária, onde o tema é sujeito a abordagens multifacetadas. Nesse sentido, pretende-se, neste artigo, perceber de que forma se aborda o tema da morte em três álbuns para crianças, dando particular atenção à articulação intersemiótica entre texto e imagens.

Palavras-chave: Morte. Avós. Literatura Infantil.

ABSTRACT - Grandparents Death in Children's Literature: an analysis of three picture books. Respecting the intelligence and sensitivity of the child, increasingly contemporary children's literature declines subjects traditionally considered taboo, such as death, through the creation of literary and visual universes with high aesthetic quality, where death is the subject of plural approaches. Thus, it is our purpose, in this article, to understand how text and images coexist and intersect themselves in three children's picture books having the death as the nuclear subject.

Keywords: Death. Grandparents. Children's Literature.

Educação \& Realidade, Porto Alegre, v. 38, n. 4, p. 1113-1127, out./dez. 2013. 
A Morte dos Avós na Literatura Infantil

Na sociedade ocidental, falar de morte às crianças continua a ser uma das principais preocupações de pais, professores e outros agentes educativos que frequentes vezes têm de dar resposta a perguntas difíceis dos mais novos sobre o que é a morte, se há vida para além dela e o que acontece às pessoas que morreram. Confusos e desorientados, muitos adultos refugiam-se na não-resposta ou em respostas de caráter evasivo, eufemístico, metafórico e simbólico, alegando frequentemente que a morte é um estado de profundo adormecimento e que a pessoa que morreu foi para o céu, que se transformou numa estrela ou num anjo, numa explicação que se inscreve claramente na tradição judaico-cristã. A sua principal preocupação consiste em apaziguar a dor da perda (ou desviar o foco de curiosidade da criança) de forma a, na sua perspetiva adulta, evitar perturbações de ordem psicológica, emocional e social no ser em crescimento, adiando assim para uma fase posterior do seu desenvolvimento emocional e cognitivo explicações mais realistas. Norbert Elias, na sua obra La Solitude des Mourants (2002), refere justamente a este propósito:

Rien ne caractérise mieux l'attitude actuelle devant la mort que la manière dont les adultes redoutent de faire connaître aux enfants les faits concrets [qui] touchent la mort [...] on a l'impression obscure qu'on [...] leur cache les réalités simples de la vie, qu'ils auront pourtant inevitablement à connaître et à comprendre (Elias, 2002, p. 31).

No entanto, o silêncio, a negação ou o recurso a explicações metafóricas e fantasiosas acerca da morte podem prejudicar o crescimento global da criança (Nunes et al., 1998). Se é certo que o adulto tem de ter em conta o estádio de desenvolvimento cognitivo e emocional em que a criança se encontra e perceber quais as concepções que ela possui sobre a morte, também entendemos que a abordagem ao tema deve ser feita de forma honesta, frontal e sem subterfúgios, embora respeitando, naturalmente, a capacidade de compreensão da criança e o seu nível de maturação psicoemocional, perspetiva defendida por Torres, para quem “[...] a abordagem do tema com a criança requer que se respeite, tanto quanto possível, a sua capacidade de abstracção. O processo de aprendizagem do que representa a morte deverá, dessa maneira, ocorrer em etapas graduais, de acordo com a capacidade intelectual e emocional da criança" (Torres apud Nunes et al., 1998, s. p.).

É, pois, importante perceber em que fase do seu desenvolvimento cognitivo e emocional se encontra a criança para encontrar a melhor forma de lhe explicar em que consiste a morte, no respeito pela sua inteligência e sensibilidade, sabendo contudo que a abordagem não poderá ser a mesma com uma criança que ainda se encontra no estádio pré-operacional e com um adolescente, que atingiu já ao estádio das operações formais. A Psicologia do Desenvolvimento pode auxiliar o educador/professor ou qualquer outro agente educativo a encontrar a melhor forma de o fazer.

1114 Educação \& Realidade, Porto Alegre, v. 38, n. 4, p. 1113-1127, out./dez. 2013 Disponível em: <http://www.ufrgs.br/edu_realidade> 
Na verdade, inúmeros estudos na área da Psicologia, em grande medida baseados na teoria psicogenética de Piaget, têm demonstrado que a evolução cognitiva da criança se processa por estádios sequenciais - sensório-motor, pré-operacional, operacional concreto e operacional formal -, num processo de equilibração progressiva que permite à criança lidar consigo própria e com o mundo envolvente de forma gradualmente estruturada e consistente, percebendo, no que à morte diz respeito, e dependendo da fase em que se encontra, conceitos como os de irreversibilidade, não-funcionalidade e universalidade (Nunes et al., 1998). É a partir do estádio das operações concretas que a criança entenderá melhor esses conceitos, percebendo que a morte é irreversível, irrevogável e permanente, isto é, que uma pessoa que morre não voltará a viver e que, portanto, a finitude da vida é uma inevitabilidade que atinge todos os seres vivos.

Por isso, como demonstraram os estudos pioneiros de KüblerRoss (1969), a atitude do adulto não deve ser a de escamotear a realidade ou de reprimir os sentimentos da criança que perdeu um ente querido, o que constitui um fator de desequilíbrio para o seu desenvolvimento, mas sim abordar o tema de forma natural e permitir que a criança expresse emotivamente a sua dor, sendo desejável que o adulto exteriorize igualmente a sua tristeza na presença da criança, como defende a autora. Também Castro (2000), mais recentemente, defende que os adultos deverão adotar basicamente duas atitudes para ajudar a criança a compreender e a lidar com a morte: fornecer toda a informação à criança e permitir a expressão de emoções:

D'une manière générale et en premier lieu, il est crucial de fournir de l'information à l'enfant. [...] Cela permet à l'adulte et à l'enfant de s'adapter, ensemble, à la réalité de la mort, et de réduire, dans la vie quotidienne, les moments de forte désorganisation [...]. En deuxième lieu, il est d'une importance capitale à l'enfant d'exprimer ses émotions. C'est lui faire comprendre que ce qu'il ressent est naturel et attendu dans une situation aussi dramatique que la perte d'un être cher (Castro, 2000, p. 142).

Deste modo, parece consensual que falar com as crianças sobre a morte deve ser encarado de forma natural, pois, se assim for, a criança estará muito provavelmente melhor preparada para enfrentar situações de perda no seu futuro. Efetivamente, diz-nos Angela Wiseman (2012, s. p.): "The way that adults recognize and respond to children's complex reactions to death is an important aspect of how they grieve”. Por força das circunstâncias, na maior parte dos casos, o primeiro contacto que as crianças têm com a morte é quando um dos avós morre. Se a atitude daqueles que lhe são próximos for a de transparência e autenticidade, envolvendo a criança nesse ambiente de tristeza vivido em família, isso pode ser decisivo para que a criança ultrapasse com alguma serenidade as fases do luto que Kübler-Ross apontou, no seu livro On Death and Dying (1969): negação e isolamento; raiva; negociação; depressão;

Educação \& Realidade, Porto Alegre, v. 38, n. 4, p. 1113-1127, out./dez. 2013. 1115 Disponível em: <http://www.ufrgs.br/edu_realidade> 
A Morte dos Avós na Literatura Infantil

aceitação. Na verdade, diz-nos a autora, anos mais tarde, que: "Children who have been allowed to participate in the death of a grandparent or relative at a young age are usually better prepared later in life when a parent or a sibling becomes terminally ill” (Kübler-Ross, 1985, p. 77).

A literatura infantil, apesar de se instituir essencialmente como fenómeno artístico, com uma inegável função estética, pode revelarse igualmente um precioso instrumento pedagógico para auxiliar pais e professores a abordar o tema da morte com as crianças. Wiseman, apoiando-se em estudos realizados por autores como Bargiel (1997) e Copenhaver-Johnson (2008), sublinha justamente que a literatura infantil tem sido identificada como um método poderoso para ajudar os mais novos a lidar com eventos traumáticos, como é o caso da morte de um ente querido. É, por isso, desejável que a criança tenha contacto, especialmente pela mão do adulto-mediador, com livros em que as personagens infantis vivenciam a experiência da morte de múltiplas formas, pois, como assinala ainda a autora, "[...] children demonstrate multidimensional ways of perceiveing and reacting to the experience [of death]" (Wiseman, 2012, s. p.).

Assim sendo, os livros para crianças podem dar respostas (mais metafórico-simbólicas ou mais realistas) às inquietações das personagens infantis (como sucede em Um Avô Inesquecivel, um dos álbuns aqui em análise, e em que o narrador omnisciente dá voz, em discurso indireto livre, aos pensamentos do pequeno João: "Olha [João] para o caixão onde está o avô. Há tantas coisas que gostaria de lhe perguntar. Se está escuro dentro do caixão. Se morrer dói. Se o avô está no céu, como diz a tia Luísa. E como é o céu" (Westera, 2005, s. p.), e, simultaneamente, como julgamos, às das crianças leitoras, que assim se projetarão no narrado, revendo-se presumivelmente de forma especular nas personagens de ficção, nas suas dúvidas e nas formas plurais como essas personagens lidam com a morte.

Também a força expressiva das imagens nos álbuns para crianças se reveste de particular significado para o leitor infantil, contribuindo para a reconstrução ou ampliação de sentidos que os textos frequentemente apenas sugerem ou insinuam. Na verdade, Sipe, num dos seus últimos estudos sobre os denominados picturebooks, conclui que: "[...] meaning conveyed in illustrations may be more significant to child readers in understanding the overall meaning of a picturebook than the words" (Sipe apud Wiseman, 2012, s. p.). Apesar de Sipe ter amplamente demonstrado que a articulação intersemiótica entre texto verbal e imagem se inscreve numa lógica de complementaridade e de sinergia que contribui para a criação de uma atmosfera poética de grande produtividade semântica, não deixa de ser um facto que, num número já significativo de álbuns que abordam o tema da morte, a imagem é mais eloquente do que a palavra, podendo criar um impacto emotivo que se revelará, provavelmente, determinante (também) ao nível da compreensão leitora da criança.

1116 Educação \& Realidade, Porto Alegre, v. 38, n. 4, p. 1113-1127, out./dez. 2013 Disponível em: <http://www.ufrgs.br/edu_realidade> 
Contudo, não se pretende, neste artigo, demonstrar as reações psicológicas e emotivas das crianças face à leitura de álbuns que abordam literariamente e no plano visual o tema da morte. Não partimos de nenhum estudo empírico efetuado com crianças em diferentes estádios de desenvolvimento (hipótese que fica em aberto para um futuro próximo) mas limitámo-nos a analisar as diferentes formas de representação estética e literária da morte que nos livros em questão se configuram. No entanto, o nosso olhar adulto permite-nos intuir que a leitura destes três álbuns não deixará o potencial recetor (não adulto e adulto) indiferente, até por se tratar de um tema que só nas últimas décadas começou a ser declinado pela Literatura Infantil.

Na verdade, a morte, outrora considerada um tema tabu e por isso arreigada do universo dos livros especificamente endereçados ao público infantil, ou sujeita a abordagens eufemísticas e fantasiosas que pretendiam desviar a curiosidade das crianças de uma realidade dura e incompreensível, como defendemos noutro lugar, tem adquirido, ultimamente, uma atenção redobrada da parte de escritores e ilustradores que, fazendo uso da sua arte, constroem universos efabulatórios e pictóricos onde o tema é abordado de forma multidimensional.

Várias são as perspetivas sobre a morte que têm surgido nas últimas décadas um pouco por todo o mundo no domínio da literatura infantil, e em particular no caso dos picturebooks. Um estudo longitudinal realizado por Wiseman nos Estados Unidos permitiu concluir que, entre 2001 e 2011, foram publicados 89 livros sobre o tema, dos quais 52 se centravam na morte de uma pessoa e 31 na de um animal. $O$ estudo mostrou igualmente que, na maioria dos livros relacionados com a morte de uma pessoa, essa pessoa é um adulto (em 17 livros a figura do pai ou da mãe, em 31 de um dos avós) (Wiseman, 2012).

No Brasil, um outro estudo efetuado por Rosa Silveira sobre a temática da velhice demonstrou que dos 60 livros publicados, na sua maioria na década de 2000, 14 aludem especificamente à morte dos avós, embora essa indicação não esteja presente nos títulos das obras, o que, na perspetiva da autora, pode servir o propósito de criar empatia com a criança leitora (Silveira, 2012).

Em Portugal, os estudos sobre o tema ainda não são significativos, talvez por ainda predominar a hegemonia do livro estrangeiro ilustrado, no que à morte diz respeito, e em particular à morte dos avós - tema que pretendemos abordar neste artigo. De entre os álbuns existentes no panorama editorial português, selecionámos apenas três, essencialmente pela diversidade de olhares sobre a morte que possibilitam: Querida Avó, de Birte Müller, Um Avô Inesquecível, de Bette Westera, e $O$ Livro da Avó, do autor e ilustrador português Luís Silva² .

Esses três belíssimos livros partem justamente do tema da morte - neste caso de um dos avós - para, de uma forma sensível e comovente, abordarem semanticamente eixos temáticos afins, como a velhice, a saudade, os afetos, a tristeza e a dor da perda. Fazem-no de diferentes

Educação \& Realidade, Porto Alegre, v. 38, n. 4, p. 1113-1127, out./dez. 2013. 1117 Disponível em: <http://www.ufrgs.br/edu_realidade> 
A Morte dos Avós na Literatura Infantil

formas: na verdade, se, em Querida Avó, se acentua a dimensão espiritualizada da morte, colocando no centro da narrativa uma personagem infantil que, apesar de triste, acredita que a alma da avó continua viva, encetando um percurso que a conduzirá às montanhas mais altas dos Andes na esperança do reencontro, em Um Avô Inesquecível a morte do avô é experienciada de forma negativa pelo protagonista, João, um menino que se recusa inicialmente a aceitar que o avô morreu. A atitude da mãe será determinante no processo de luto da criança, convencendo o filho a participar nas cerimónias fúnebres e ajudando-o a superar a dor da perda, tudo num registo discursivo em que sobressai o recurso a um léxico semanticamente associado à morte. Já em O Livro da Avó, a narração autodiegética, em analepse, dá conta da imensa saudade que o protagonista adulto sente da avó, evocando no seu discurso interior as memórias longínquas de um passado que a memória subjetiva insiste em presentificar. As ilustrações, que complementam e iluminam o texto verbal, reforçam, sobretudo através do simbolismo das cores e do contraste luz/sombra, o tom que predomina nos álbuns de Müller, Westera e Luís Silva: de esperança, no primeiro caso, de recusa e revolta, no segundo, de saudade, no caso do álbum do autor e ilustrador português.

O primeiro dos álbuns aqui em análise - Querida Avó -, escrito e ilustrado pela autora suíça Birte Müller, surge na sequência de uma experiência cultural vivida pela autora na Bolívia: a participação no ritual das comemorações do dia de Todos os Santos. Esse é o mote que servirá de inspiração para Müller dar conta, no seu livro, dos hábitos e costumes dos membros de uma comunidade sul-americana cuja crença religiosa, filiada na tradição judaico-cristã, os faz acreditar na vida depois da morte.

Trata-se de um álbum narrativo cuja ação se desenrola numa aldeia no alto dos Andes, sendo que a narrativa verbal e visual permite à criança-leitora europeia contactar, pela mediação da leitura, com uma realidade cultural que não lhe é familiar, nomeadamente com os hábitos, os costumes e a crença religiosa de uma comunidade sul-americana que festeja alegremente uma vez por ano, no dia de Todos os Santos, o regresso das almas que os vêm visitar, como se pode ler no posfácio. Nesse aspeto, a obra tematiza a morte enfatizando a sua dimensão espiritual, dimensão essa que não é abordada, pelo menos de forma explícita, nas duas outras obras aqui em análise.

A personagem principal é Felipa, uma menina que se esforça por conviver com a perda da avó e com a tristeza que ficou após a sua morte. No entanto, esta menina sabe que a alma das pessoas não morre, continua a viver, e por isso inicia um percurso solitário em direção ao alto das montanhas dos Andes na tentativa (frustrada) de a encontrar.

No início da narrativa, a protagonista sente-se muito triste porque a avó, que já estava muito velhinha, faleceu. A ilustração confirma esse estado de espírito da menina, que surge simbolicamente sentada no meio de uma estrada, desamparada e só, e com uma expressão facial

1118 Educação \& Realidade, Porto Alegre, v. 38, n. 4, p. 1113-1127, out./dez. 2013 Disponível em: <http://www.ufrgs.br/edu_realidade> 
que o leitor presumivelmente interpretará como sendo de tristeza. No entanto, essa tristeza é mitigada pela crença de que a alma da avó continua viva, como refere o narrador, dando-lhe tal convicção alento para a procurar.

Nesse percurso de indagação, numa primeira fase, a menina pede auxílio aos animais. Começa por perguntar pela alma da avó ao Burrico, que não lhe dá qualquer resposta; depois pede ajuda ao porquinho Chancho e aos seus amigos, que a procuram por todo o lado sem a encontrarem; e, por fim, aos lamas da Avó, que, tal como o Burrico, também ficam em silêncio.

Após três tentativas fracassadas, e com a menina sem saber o que fazer, a narrativa prossegue com um diálogo entre a Mãe e Felipa. A menina questiona a mãe para saber onde está a alma da avó e a mãe responde-lhe que está no Céu, por cima das montanhas cobertas de neve.

À luz da teoria platónica da imortalidade e do catolicismo, a resposta da Mãe traduz a crença filosófica e religiosa de que, com a morte, apenas cessam as funções vitais do corpo. A alma passa a habitar um outro espaço, etéreo, imaterial, onde poderá descansar em paz. Essa convicção apazigua a dor da perda e por isso é natural que esta menina, apesar de triste, aceite com normalidade a morte da avó, sem drama, angústia ou revolta. No fundo, ela encontra-se na última fase do luto a que se refere Kübler-Ross, não havendo, na narrativa, alusão às fases anteriores de negação e isolamento, raiva, negociação ou depressão (Kübler-Ross, 1969, p. 265). Há, sim, o desejo irreprimível do reencontro e, por isso, a menina parte sozinha, rumo à mais alta montanha, em busca da alma da avó.

Mas, essa busca revela-se infrutífera, pois, como nos diz o narrador, “[a montanha] é demasiado longe. Por mais que [Felipa] caminhe, não parece aproximar-se dela” (Müller, 2004, s. p.). A estratégia visual de representar plasticamente a menina de perfil e em movimento, no centro da página, num espaço aberto em que se vislumbram, ao longe, as montanhas, um espaço desprovido da presença de outros humanos, concede-lhe protagonismo e reforça a ideia do percurso árduo e solitário desta criança, movida por uma fé inabalável.

É o Pai quem, ao final do dia, encontra finalmente a menina, com fome e frio, cheia de medo do escuro, e a leva para casa, sã e salva. É ainda o Pai quem lhe explica que "Não se pode ir visitar as almas assim, sem mais nem menos [...]. Elas moram no seu próprio mundo; moram nas montanhas e, na Terra, estão em tudo aquilo que cresce. Mas uma vez por ano vêm visitar-nos, e fazemos uma grande festa" (Müller, 2004, s. p.).

As palavras do Pai reforçam a ideia de que as almas habitam num lugar longínquo e inacessível, deixando implícita a ideia de que devemos respeitar o seu descanso e esperar que regressem, uma vez por ano, para visitar os vivos. Ao contrário da Mãe, que assume uma perspetiva

Educação \& Realidade, Porto Alegre, v. 38, n. 4, p. 1113-1127, out./dez. 2013. 1119 Disponível em: <http://www.ufrgs.br/edu_realidade> 
A Morte dos Avós na Literatura Infantil

teológica católica ao afirmar que as almas moram no Céu, o Pai introduz no discurso uma visão predominantemente panteísta ao explicar que as almas estão em tudo aquilo que cresce, na Terra. Estas duas perspetivas, aparentemente dissonantes, sinalizam apenas a heterogeneidade de convicções e crenças religiosas que coexistem num mesmo território, como é o caso desta comunidade sul-americana. Nessa medida, a obra apela à aceitação das diferenças individuais e culturais, num claro propósito de promover a educação intercultural junto dos mais novos.

Na terceira parte da narrativa, assiste-se à preparação do dia de Todos os Santos, com a família reunida na cozinha, confecionando comida e enfeitando as mesas: "Todos ajudam na cozinha. [...] Está tudo disposto sobre mesas enormes e decorado com flores" (Müller, 2004, s. p.). Este ambiente festivo, de celebração e de alegria, evidencia um aspeto cultural que contrasta com a cultura europeia, permitindo, uma vez mais, à criança leitora perceber que existem diferentes formas de perspetivar a morte e de recordar os que já partiram. Isso é por demais evidente na seguinte passagem do texto: "Durante um dia e uma noite, toda a aldeia festeja com as almas, que estão de visita. Na manhã seguinte, seguem para o cemitério, levando consigo todas as comidas. As campas estão todas muito enfeitadas. Felipa gosta muito dos festejos no cemitério" (Müller, 2004, s. p.).

A ilustração confirma a existência desse ambiente festivo, representando visualmente um grupo de pessoas sorridentes, onde se inclui uma criança, que dançam ao som de uma flauta tocada por um dos homens. Juntamente com o grupo, encontramos um porco, que presumivelmente acompanhará estas pessoas até ao cemitério, estratégia icónica que sinaliza a proximidade e a comunhão entre o Homem e a natureza.

O ritual praticado pelos membros desta comunidade sul-americana contrasta com a tristeza que, invariavelmente por toda a Europa, invade os vivos nesse dia primeiro de novembro, em que se chora os mortos e se reza pela sua alma. As visitas ao cemitério, que normalmente estão interditas a crianças na maioria dos países europeus, não constituem aqui motivo de alegria ou de celebração. Pelo contrário.

Muito provavelmente, a criança leitora que não conhece a realidade e a cultura sul-americanas sentirá um particular interesse ao ler esta obra, compreendendo que, de cultura para cultura, os hábitos, os costumes, os rituais, as crenças variam, o que é claramente benéfico para alargar a sua visão do mundo e valorizar as diferenças étnicas e culturais, contribuindo a obra, nesse aspeto, como referimos anteriormente, para a educação intercultural dos mais novos. Ao mesmo tempo, a mensagem positiva que esta obra transmite acerca da morte pode aliviar tensões e angústias (como o medo e a dor da perda), instituindo-se este magnífico álbum para o potencial recetor infantil, nessa medida, também como um instrumento pedagógico que pode auxiliar pais e outros agentes educativos a abordar o tema com os mais novos. Essa

1120 Educação \& Realidade, Porto Alegre, v. 38, n. 4, p. 1113-1127, out./dez. 2013 Disponível em: <http://www.ufrgs.br/edu_realidade> 
mensagem positiva é particularmente visível no desfecho da narrativa, quando Felipa, apesar de ficar um bocadinho triste se despede da alma da Avó: “Adeus, Avó, até para o ano!” (Müller, 2004, s. p.).

Ou seja, existe aqui a esperança num reencontro que se repete anualmente, e pelo qual se aguarda ansiosamente durante todos os dias que o antecedem, aliviando dessa forma a angústia de um não retorno.

Do ponto de vista visual, a ilustração artística deste álbum, assim o cremos, cativa o leitor pelo recurso a uma paleta de cores fortes e quentes e a uma iconografia simbólica que acentua o exotismo da paisagem, dos trajes e dos costumes dos habitantes desta aldeia no alto dos Andes, e que, para além disso, transmite à criança sentimentos positivos face à experiência da morte. Texto e imagem articulam-se pois harmonicamente, criando uma atmosfera que, para além do que atrás fica dito, seduz e provoca deslumbramento.

Já em Um Avô Inesquecível, de Bette Westera, o tema da morte é abordado de outra forma. Na verdade, e pese embora a existência de uma atmosfera poética potenciada pela coesão intersemiótica entre texto e imagens, o recurso (sem subterfúgios) a um léxico associado à área semântica da morte - funeral, caixão, cova - institui-se de certo modo como inesperado e desconcertante, mas tem o mérito de assim se demonstrar ao potencial recetor infantil que a morte é uma inevitabilidade - como inevitável é o profundo sofrimento que provoca nos que veem partir os que mais amam.

As ilustrações a sépia que percorrem grande parte do livro acentuam precisamente o vazio afetivo e existencial que a morte do avô provoca na criança aturdida e sem capacidade de reação, como se a vida tivesse perdido momentaneamente a cor, como se as emoções toldassem o espírito de quem, por esse motivo, não consegue ter do real mais do que uma visão desfocada, parcelar e fragmentada. A técnica da aguarela permite justamente esbater contornos, diluir as formas e conferir à narrativa visual um tom impressionista que convida o leitor a atribuir sentidos plurais à composição plástica que se lhe oferece ao olhar. No entanto, o lenço vermelho-sangue, contrastando com a neutralidade do tom sépia dominante, é o sinal de que a vida continua e de que os afetos perduram muito para além da partida daqueles que mais amamos.

Estruturalmente, a narrativa obedece a um esquema tripartido, iniciando com o diálogo entre a criança e a mãe a propósito da morte do avô, seguindo-se a evocação (em analepse e pela focalização omnisciente do narrador) de episódios que marcaram a relação de afeto e cumplicidade entre avô e neto, para finalizar com a aceitação da morte, por parte da criança, que encontra, nesse seu percurso interior, motivos para voltar a sorrir.

Na verdade, no início da narrativa, a personagem infantil deste magnífico álbum encontra-se na fase de negação e isolamento a que se refere Kübler-Ross, debatendo-se interiormente com sentimentos con-

Educação \& Realidade, Porto Alegre, v. 38, n. 4, p. 1113-1127, out./dez. 2013. 
A Morte dos Avós na Literatura Infantil

traditórios que atestam a sua revolta e o seu inconformismo. Na verdade, João recusa inicialmente deixar o espaço íntimo da sua privacidade porque é lá que ainda se encontra o corpo já sem vida do avô e a criança não quer (ou não pode) abandoná-lo: "Eu não vou [...]. Vou ficar aqui, com o avô" (Westera, 2005, s. p.). Essa atitude sinaliza a recusa da criança em aceitar a morte do avô, sendo claro o desejo (utópico) de permanecer para sempre (literal ou metaforicamente) a seu lado.

O deítico aqui é transformado num ambiente íntimo e familiar na ilustração que o representa e interpreta: um ambiente rodeado de objetos que o leitor presume terem pertencido ao avô - a secretária ainda aberta, um relógio de pulso, uma caneta, um tinteiro e a poltrona, onde a criança, desamparada e só, se aninha como se pedisse proteção. Altamente produtivo do ponto de vista semântico é o facto de a figura materna, presente no texto verbal, ser simplesmente elidida da ilustração, conferindo-se desta forma o protagonismo visual à criança para demonstrar o estado de profundo desamparo afetivo em que esta se encontra, rodeada apenas dos objetos que lhe fazem ainda manter intacta a memória do avô. No fundo, a criança não consegue (ou não quer) desligar-se dos objectos para assim se sentir fisicamente mais próxima do seu avô inesquecível.

Poder-se-á ainda afirmar que esse mesmo espaço familiar que acolhe no presente o corpo sem vida do avô e onde a criança se sente profundamente triste e desamparada foi, num tempo irremediavelmente perdido, um espaço de alegria e cumplicidades, pelo que não surpreende que esse seja o espaço em que a criança se sente afetiva e simbolicamente mais próxima do seu avô.

Contudo, a intervenção da mãe, que, sem qualquer tipo de complacência ou de eufemismos, lhe diz "Não pode ser [...]. O avô morreu" (Westera, 2005, s. p.), obriga involuntariamente a criança a enfrentar a morte, mesmo que a reação emotiva ulterior da criança seja o choro compulsivo, tal como poeticamente se percebe pela voz do narrador: "As lágrimas ardiam-lhe nos olhos" (Westera, 2005, s. p.). Essa exteriorização da dor atesta, e em definitivo, a aceitação de uma evidência - a morte do avô -, mas não ainda a superação do trauma.

Porém, a intervenção da mãe não se limita a confrontar a criança com a dura realidade, uma vez que é ela quem a ajudará a enfrentar e a ultrapassar a tristeza e o vazio que o desaparecimento do avô lhe provocou no mais profundo do seu ser, oferecendo-lhe um lenço - o lenço do avô. Esse objeto pessoal e íntimo surge como forma de ligação entre o passado e o presente, dando continuidade simbólica e, de certo modo, física a essa relação afetiva tão especial entre avô e neto. O lenço servirá de pretexto para evocar, através da voz do narrador omnisciente (e em analepse), as brincadeiras e cumplicidades entre ambos, contribuindo, de certa forma, para o apaziguamento da dor do pequeno João.

A ilustração, jogando com o contraste cromático entre o tom sépia dominante e o vermelho rubro do lenço, reveste-se aqui de uma enor-

1122 Educação \& Realidade, Porto Alegre, v. 38, n. 4, p. 1113-1127, out./dez. 2013 Disponível em: <http://www.ufrgs.br/edu_realidade> 
me relevância, complementando e enriquecendo o texto verbal, preenchendo e ampliando os sentidos propositadamente deixados em suspenso pelo código linguístico-literário.

A segunda parte da obra é preenchida com a rememoração das brincadeiras entre avô e neto, servindo de pretexto para testemunhar a afetividade e a cumplicidade entre ambos mas também a personalidade irreverente de um avô muito especial que, contrariamente aos outros adultos, e à revelia das suas imposições, é capaz de brincar aos cowboys e aos piratas, um avô que contraria as normas instituídas e que gosta de batatas fritas, de sanduíches com muita manteiga de amendoim e montes de compota.

Nas aquarelas que acompanham, completam e interpretam o texto verbal, o lenço vermelho funciona como elemento unificador da narrativa visual, contrastando com o tom sépia que perpassa o livro. As opções ilustrativas de van Straaten passam igualmente pela representação icónica, nesta parte da obra, de um gato (não referido pelo código escrito) que funciona como cúmplice secreto das travessuras entre avô e neto, o que demonstra que a ilustração não é uma mera tradução ou repetição do legível. Pelo contrário, a ilustração interpreta, ilumina, complementa e enriquece o texto verbal, fazendo-o respirar e estabelecendo com ele uma interrelação dialogal que facilita a instauração de uma atmosfera de verdadeira pregnância significativa.

A última parte da obra retoma o presente e, nela, a criança acompanha o funeral até ao cemitério, embora (pela voz do narrador omnisciente, e em discurso indireto livre) se questione sobre a forma como os crescidos participam no cortejo fúnebre: "João não sabia que os crescidos podiam andar tão devagar. Nas ruas da cidade andavam sempre a correr..." (Westera, 2005, s. p.). Ao olhar para o caixão, a criança sente que há tantas coisas que gostaria de perguntar ao avô, porque as respostas dos crescidos não o satisfazem.

Quando o corpo do avô desce à cova, João recusa deitar terra para cima do caixão e não consegue evitar as lágrimas, mas a mãe, sempre atenta, oferece-lhe de novo o lenço do avô: “- Toma, é para ti [...]. Dá-lhe um grande nó” (Westera, 2005, s. p.). Ora, o avô tinha o hábito de dar um nó no seu lenço para não se esquecer de nada. Por isso, ao dar o nó no lenço do avô, a criança garante que nunca mais se esquecerá do seu avô e que, assim sendo, os laços entre ambos são simbolicamente indestrutíveis, por toda eternidade.

Em estreita articulação semântica com os álbuns de Bette Westera e de Birte Müler, O Livro da Avó pode igualmente ser percepcionado como um álbum de enorme riqueza plástica e literária sobre a perda, embora divirja dos livros anteriores essencialmente pela representação temporal dos factos (aqui evocados pela memória subjetiva do narrador) e pela focalização adotada (narração autodiegética).

Na realidade, neste belíssimo álbum de invulgares dimensões, o narrador adulto, provável figura especular do autor, socorre-se de um

Educação \& Realidade, Porto Alegre, v. 38, n. 4, p. 1113-1127, out./dez. 2013. 1123 Disponível em: <http://www.ufrgs.br/edu_realidade> 
A Morte dos Avós na Literatura Infantil

registo pessoal e intimista para, em analepse, evocar a avó há muito desaparecida e expressar a profunda saudade que o tempo não diluiu. A projeção autobiográfica no narrado é, aliás, assumida pelo autor/ilustrador, ao afirmar, em entrevista recente: "[...] o principal "motor" da sua [do livro] composição foi o exercício de expor uma parte da minha vida em que a minha avó ocupou um lugar central ${ }^{3 ”}$ (Silva, 2010, s. p.).

Tal como sucede nos álbuns de Westera e de Müller, O Livro da Avó tem como eixos temáticos aglutinadores a morte e a saudade. No entanto, ao contrário de Um Avô Inesquecível e de Querida Avó, em que duas crianças são confrontadas com a morte mais ou menos recente dos avós, na obra de Luís Silva, como se refere intratextualmente, “[...] muitos anos passaram” (Silva, 2007, s. p.) desde o desaparecimento da avó. Ainda assim, o tempo não conseguiu apagar as memórias de um sujeito textual que assume, no presente, continuar a sentir a falta dessa avó tão especial, o que significa que a dor da perda persiste, apesar do fosso temporal que separa o antes e o agora.

Do ponto de vista da estrutura técnico-compositiva, é interessante referir que a narrativa inicia evocando as palavras longínquas da avó, que, um dia, dirigindo-se ao neto, lhe disse "Fazes-me falta" (Silva, 2007, s. p.). Tais palavras ecoam ainda na memória subjetiva do narrador, a tal ponto que é com elas que se fecha a narrativa (embora sejam desta vez pronunciadas pelo neto-adulto e endereçadas a esse ser ausente e fantasmático que a saudade insiste em presentificar).

Graficamente, a frase surge transcrita em carateres de grande dimensão, ocupando a totalidade da página em branco que dá por concluída a narrativa. Rompendo com a sequência verbal e icónica até então dominante - código linguístico na página da esquerda, ilustração na da direita -, numa estratégia semionarrativa que desconcerta o leitor pela imprevisibilidade de que se reveste, a última página do livro, dispensando a imagem, funciona como um grito do sujeito - um grito que atesta a dimensão do seu afeto e da saudade pela avó há muito desaparecida.

Para além dessa particularidade em termos de arquitetura narrativa, há a assinalar o facto de uma parte considerável da obra se apoiar no registo retrospetivo para evocar cenas da infância, episódios marcantes que a memória não apagou, e a presença constante da avó. No fundo, essa pulverização no discurso das memórias subjetivas do narrador sinaliza a impossibilidade de selecionar as mais marcantes, de as resumir, o que é corroborado pelo recurso intencional às reticências para marcar a dificuldade de tudo dizer.

Essa sequência de episódios evocados é bruscamente interrompida no momento em que o discurso verbal, de forma direta mas simultaneamente plurissignificativa, anuncia: "Uma vez voltei e ela não estava lá!!” (Silva, 2007, s. p.). O advérbio de lugar remete o leitor de imediato para a ideia de casa - a casa da avó onde o sujeito foi tão feliz -, mas a opção ilustrativa - a representação icónica de uma janela fechada - é

1124 Educação \& Realidade, Porto Alegre, v. 38, n. 4, p. 1113-1127, out./dez. 2013. Disponível em: <http://www.ufrgs.br/edu_realidade> 
altamente produtiva do ponto de vista semântico-simbólico, pela pluralidade de leituras que potencia.

Após essa imagem, de uma força perlocutória e de uma eficácia comunicativa evidentes, existe apenas o silêncio de uma página vazia, somente preenchida pela tonalidade ocre que serve de pano de fundo ao discurso verbal em todo o livro. O silêncio é, contudo, eloquente e comunicante, dizendo muito mais do que qualquer palavra nesse momento de verdadeira intensidade dramática. À direita, a sugestiva e polissémica ilustração - representando céu e mar - desafia o leitor a aventurar-se pelos caminhos do inefável, auxiliando-o a desocultar o que propositadamente ficou por dizer.

A imagem, neste caso, impõe-se de forma soberana sobre o texto, substituindo-o, ultrapassando-o até. Aliás, o próprio autor se refere a essa passagem da obra sublinhando a dimensão semântica de que a imagem se reveste: "Limitei-me a contar o que naquele dia vi: a persiana da janela descida, ilustração perfeita do que estava a acontecer, e que me limitei a reproduzir. Falei pouco porque estava lá a imagem para dizer o resto"” (Silva, 2010, s. p.).

A partir daqui, a narrativa pictórico-verbal prossegue (e termina) dando conta de que "Muitos anos se passaram" (Silva, 2007, s. p.) desde esse dia, mas que, apesar disso, o sujeito da enunciação continua a sentir uma profunda saudade da avó. A estratégia plástica encontrada para representar o Eu que se inscreve no discurso verbal (e que conduz todo o fio narrativo) é de grande produtividade semântica. Na verdade, ao representar um adulto, de costas, sentado a uma secretária, num ambiente intimista e em atitude de recolhimento e de introspeção, a ilustração sugere uma identificação provável entre narrador e autor, porque o sujeito representado é um sujeito que se deduz ter sido o autor das palavras que surgem na última página do livro - "Fazes-me falta" (Silva, 2007, s. p.).

Assim, e em síntese, podemos concluir que, neste álbum, o dialogismo entre a componente verbal e a pictórica potencia o surgimento de uma atmosfera poética que favorece a unidade estética e semântica da obra. Se, como nos parece evidente, o texto obedece a uma lógica de economia e simplicidade que contrasta com a ilustração, muito sugestiva e abundantemente enriquecida com elementos pictóricos não explicitados pelo discurso verbal, também não deixa de ser verdade que essas duas linguagens artísticas mantêm entre si uma relação de complementaridade e de interdependência discursiva que se afigura imprescindível na formação estético-literária do recetor infantil, permitindo-lhe efetuar leituras plurais e significativas.

Na verdade, a ilustração, em perfeita consonância com o texto verbal, não se limita a traduzir ou a explicar o legível (Maia, 2002), até porque "[...] ela não lida com o legível mas com o invisível, com aquilo que se esconde atrás das linhas do texto e permanentemente se oferece e escapa aos sentidos" (Maia, 2002, p. 3): a ilustração interpreta, recria

Educação \& Realidade, Porto Alegre, v. 38, n. 4, p. 1113-1127, out./dez. 2013.1125 Disponível em: <http://www.ufrgs.br/edu_realidade> 
A Morte dos Avós na Literatura Infantil

visualmente o código linguístico, iluminando-o, complementando-o, enriquecendo-o, interagindo com ele e estabelecendo com ele uma relação de profunda coesão estética e semântica.

Não será, por isso, por mero acaso que este magnífico álbum para crianças apresenta um formato invulgar, de grandes dimensões: tratase, no fundo, de acentuar a ideia que perpassa toda a obra - a de que a saudade daqueles que amamos e que um dia vimos partir é muito grande. Tão grande como este livro.

Em suma, se, como assinala Angela Wiseman, “[...] children's picturebooks can provide a way to address and suport children as they experience trauma and begin to understand the emotions surrounding their grief" (Wiseman, 2012, s. p.), os álbuns Querida Avó, Um Avô Inesquecivel e $O$ Livro da Avó são disso exemplo inequívoco. Na verdade, apesar da sua inquestionável qualidade estético-literária, estes três magníficos álbuns instituem-se como preciosos instrumentos pedagógicos na medida em que podem auxiliar os adultos-mediadores a abordar o tema da morte e a encontrar respostas que ajudem as crianças a exteriorizar as suas emoções e a lidar com o sofrimento e a saudade dos que já partiram.

Sabemos que as reações emotivas das crianças face à morte dependem do seu desenvolvimento individual, em termos psicológicos e cognitivos, mas também do contexto sociocultural em que estão inseridas. Assim sendo, o adulto-mediador deverá atender a todos esses aspetos e encontrar a melhor forma de abordar o tema, convocando os seus saberes acerca do desenvolvimento infantil mas também fazendo uso da sua sensibilidade. A Literatura Infantil, em geral, e os álbuns aqui analisados, em particular, pela forma poética e sensível como abordam a temática da perda, pela qualidade dos textos e das ilustrações que os complementam e iluminam, pela eficácia comunicativa que resulta da profunda coerência intersemiótica entre as duas linguagens artísticas - verbal e icónica -, e ainda por possibilitarem múltiplas hipóteses interpretativas que decorrem da natureza plurissignificativa dos textos e das imagens, podem instituir-se como um poderoso aliado do adulto na difícil e complexa tarefa de dar explicações sobre a morte e amenizar a dor de quem perdeu um ser amado. Sempre no respeito pela inteligência e pela sensibilidade da criança.

Recebido em 26 de março de 2013 Aprovado em 27 de setembro de 2013

\section{Notas}

1 Este artigo deriva, parcialmente, de uma comunicação apresentada no $32^{\circ}$ Congresso IBBY, em Santiago de Compostela, em 2010. O texto original foi entretanto reestruturado e ampliado dando origem ao artigo que aqui se apresenta.

2 Coincidindo com as conclusões do estudo realizado por Silveira no Brasil, também nestes três casos a estratégia de não fazer, no título, referência à morte do avô ou da avó acentua, na nossa opinião, a dimensão afetiva presente nos livros.

1126 Educação \& Realidade, Porto Alegre, v. 38, n. 4, p. 1113-1127, out./dez. 2013. Disponível em: <http://www.ufrgs.br/edu_realidade> 
3 Disponível em: <http://rascunho.iol.pt/>. Acesso em maio de 2010.

4 Disponível em: <http://rascunho.iol.pt/>. Acesso em maio de 2010.

\section{Referências}

CASTRO, Dana. La Mort pour de Faux et la Mort pour de Vrai. Paris: Albin Michel, 2000.

ELIAS, Norbert. La Solitude des Mourants. Paris: Christian Bourgois éditeur, 2002.

KÜBLER-ROSS, Elisabeth. On Death and Dying. 1969. Disponível em: <http:// selfdefinition.org/afterlife/Elizabeth-Kubler-Ross-On-Death-and-Dying.pdf $>$. Acesso em: setembro de 2013.

KÜBLER-ROSS, Elisabeth. On Children and Death. New York: Touchstone, 1985. MAIA, G. O Visível, o Legível e o Invisível. Malasartes, n. 10, p. 3-8, 2002.

MÜLLER, Birte. Querida Avó. Porto: Ambar, 2004.

NUNES, D. et al. As Crianças e o Conceito da Morte. In Psicologia: Reflexão e Crítica, 1998. Disponível em: <http://www.scielo.br/scielo.php?pid=S010279721998000300015\&script=sci_arttext>. Acesso em: maio de 2013.

SILVA, L. O Livro da Avó. Porto: Edições Afrontamento, 2007.

SILVA, L. Entrevista. 2010. Disponível em: <http://rascunho.iol.pt/artigo. php?id=1992> . Acesso em: maio de 2010 .

SILVEIRA, R. Velhice e Morte na Literatura Para Crianças: apontamentos sobre o que e como se ensina a elas. 2012. Disponível em: <http://www.ucs.br/etc/ conferencias/index.php>. Acesso em: setembro de 2013.

WESTERA, Bette. Um Avô Inesquecível. Lisboa: Livros Horizonte, 2005.

WISEMAN, A. Summer's End na Sad Goodbyes: children's picturebooks about death and dying. In: Children's Literature in Education. 2012. Doi 10.1007/ s10583-012-9174-3. Acesso em: setembro de 2013.

Teresa de Lurdes Frutuoso Mendes é doutorada em Estudos Literários, professora no Instituto Politécnico de Portalegre e investigadora do Centro de Estudos Comparatistas da Universidade de Lisboa. É presidente da Área Científica de Língua e Literatura Portuguesas, Diretora do Curso de Educação Básica e membro de diversos órgãos colegiais na ESEP. É autora de vários artigos e comunicações nas áreas da leitura, literatura infantojuvenil e ilustração.

E-mail: teresa.mendes@esep.pt 